\title{
Status of Battery in Indonesia to Support Application of Solar PV with Energy Storage
}

\author{
I.P.G.I. Dwipayana ${ }^{1}$ I.N.S. Kumara ${ }^{2 *}$, and I.N. Setiawan ${ }^{3}$ \\ ${ }^{1,2,3}$ Departement Electrical Engineering, Faculty of Engineering \\ Udayana University \\ Bukit Jimbaran - Bali, Indonesia \\ satya.kumara@unud.ac.id
}

\begin{abstract}
Indonesia plans to build solar PV plants to reach 6500 MW capacity by 2025. One of the solar PV applications is systems with battery storage systems. In this system, the battery is an important component of the solar PV system as it stores the energy for use when the sun is unavailable. This article reviews the status of batteries in Indonesia to support the proliferation of solar PV applications. The objective is to compile a battery database for solar PV applications. The database provides insight into technology and the availability of batteries. The database consists of 361 batteries of various technologies such as FLA, VRLA, VRLA gel, VRLA AGM, and Lithium-ion. The most widely available is the VRLA gel. In terms of voltage, batteries are available at 2 to 12 volts and with capacity from 1 to $3000 \mathrm{Ah}$. The availability of batteries shows that this field is ready to support the development of solar PV with energy storage although the field of battery recycling or its waste management requires more attention.
\end{abstract}

Index Terms - Battery technology, lead acid battery, deep cycle battery, valve regulated lead acid

\section{INTRODUCTION}

The General Plan of National Energy or RUEN is a guideline for directing national energy management to realized energy independence and national energy security in supporting sustainable national development. The General Plan of National Energy states that Indonesia plans to build a solar PV capacity of 6,5 GW by 2025 and increasing to $45 \mathrm{GW}$ by 2050 [1]. Solar PV is a renewable energy source and is available as long as the sun. Also, the solar PV is a clean and environmentally friendly source, does not generate noise, it has no rotating parts, and does not produce gas emissions.

A solar PV plant is a generator that can convert sunlight into electrical energy. Solar PV plant utilized solar energy to generate Direct Current (DC) electricity. If necessary, it can be converted into Alternating Current (AC) electricity with the help of an inverter. The main components used in solar PV systems are PV modules, inverters, batteries, and control systems.

Indonesia has benefitted from solar PV applications such as Solar Home System (SHS). The implementation of SHS is used at residentials that are far away and difficult to reach by the utility such as in Papua, Kalimantan, and Sulawesi islands. The advantage of this system is that the product package is compact and simple, so it is easy to install and maintain. Another PV application that has also been developed is centralized solar PV. The systems are widely used to provide energy access for villages in mountainous areas, islands, and remote locations. Typically, the system has a large capacity to supply power from tens to hundreds of households. The advantage of this system is that it has a centralized application model, which makes monitoring and maintenance easier. Solar PV has also been used for water pumping applications to supply villages with clean water. Most of these types of solar PV applications are equipped with the battery as energy storage as energy demand normally occurs at night.

In Bali, the use of a centralized solar PV plant is used in Ban Village Karangasem with a capacity of $6 \mathrm{kWp}$ [2]. Solar PV for water pumps used in Tianyar Tengah Village Karangasem with a capacity of $20 \mathrm{kWp}$ [3]. Also, several locations use rooftop PV including the Governor's Office with a capacity of $158 \mathrm{kWp}$ [4], Udayana University Campus with a capacity of $26,4 \mathrm{kWp}$ [5], and PT. Indonesia Power Pesanggaran with a capacity of $24 \mathrm{kWp} \mathrm{[6].}$

Batteries are one of the components in solar PV systems to store energy for use at night or power buffering due to weather conditions during the daytime. The intermittent nature of solar energy has driven the research and development of battery technology. Currently, lithium-ion batteries are the most widely available battery type and come in a variety of sizes. The price is still relatively high, in the range of 1000-2000 USD/kWh. Research and development processes that would be able to reduce battery prices in the next 5 to 10 years. In the context of Indonesia, according to the Secretary-General of The Ministry of Industry, Syarif Hidayat, the problem in the solar PV application is the 
battery. After many PV plants were built and operated, the batteries were found to be damaged. This has resulted in poor power plant operations. This component has not developed domestically yet, so it is still imported [7].

At present, a maintenance-free type lead-acid battery has been developed in which a control valve is used in the system. This battery application is widely used in the automotive, marine, telecommunications, and Uninterruptible Power Supply (UPS) industries. However, for large scale grid applications, conventional lead-acid batteries are still the best alternative. The fluctuating conditions that occur in grid systems that use renewable energy such as solar PV system, leads to battery problems in the form of short life cycles and extra maintenance. Several overseas lead-acid battery manufactures have made several improvements by adding carbon to the electrodes to increase power output and reduce adverse chemical reactions in the battery cells [8].

To support the supply of clean energy, the industry plays an important role in the mass production of a secondary battery. In Indonesia, the battery industry only produces a secondary battery type of Starting, Lighting, and Ignition (SLI) for cars and motorcycles. Many deep cycle batteries are still imported from China. Domestically, the development of battery technology is rather slow. Currently, a study is underway to develop a lithium battery for electric vehicles [8]. Batteries have an important role in the solar PV system, therefore research and development are needed as well as strong national manufacturing facilities to support the proliferation of solar PV applications.

This article reviews the development battery in Indonesia. The review covers technical specifications and technology of battery, battery standards, battery manufacturers, and battery recycling. The objective of this study is to produce a battery database for the solar PV plant application as an insight for researchers, solar PV plant designers, and the general public who plan to build solar PV systems and adapt it to the technology or battery models that available in the country.

\section{II.BATTERY AS AN ENERGY STORAGE}

\section{A. Battery Technology}

A battery is a device that can convert the chemical energy contained in the active ingredients of the battery components into electrical energy through an electrochemical reaction or reduction and oxidation [9].

Battery technologies are based on their basic components such as lead-acid, Ni-MH, Ni-Cad, and Li-on. The lead-acid battery is a battery composed of lead oxide as the cathode, lead metal sponge as the anode, and sulfuric acid as an electrolyte. Batteries nickel-cadmium (Ni-Cad) is a battery that uses nickel hydroxide $\mathrm{NiOH}_{2}$ as the cathode 1.and cadmium $(\mathrm{Cd})$ as an anode separated by alkaline potassium hydroxide as the electrolyte. The nickel-metal hybrid (Ni-MH) battery has almost the same characteristics as a nickel-cadmium battery. The difference lies in the use of the material for its anode, which is a metal hybrid made from a mixture of lanthanum. Battery lithium-ion (li-on) uses lithium iron phosphate $\left(\mathrm{LiFePO}_{4}\right)$ as the cathode and the carbon (C) as the anode. Table 1 presents a summary of the advantages and disadvantages of batteries based on their technology [8].

TABLE I

ADVANTAGES AND DISADVANTAGES BATTERY BASED ON TECHNOLOGY

\begin{tabular}{|c|c|c|}
\hline $\begin{array}{c}\text { Battery } \\
\text { Technology }\end{array}$ & Advantages & Disadvantages \\
\hline Lead Acid & $\begin{array}{l}\text { Material of battery production is cheap, } \\
\text { tolerance to overcharging, many } \\
\text { manufactures, maintenance free. }\end{array}$ & $\begin{array}{l}\text { Efficiency of battery is low enough } \\
(70 \%) \text {, the mass of battery is very } \\
\text { heavy, percentage of DoD } 50 \%\end{array}$ \\
\hline $\mathrm{Ni}-\mathrm{MH}$ & $\begin{array}{c}\text { Energy density is twice bigger than lead } \\
\text { acid and ( } 25-40 \%) \text { bigger than Ni-Cad, } \\
\text { battery tend to be environmentally friendly, } \\
\text { low battery internal impedance, life cycle is } \\
\text { quite high ( } 500 \text { cycles), high depth of } \\
\text { electrical energy release. }\end{array}$ & $\begin{array}{l}\text { High speed of self-discharge, there is } \\
\text { memory effect, efficiency is quite low } \\
\qquad(65 \%) .\end{array}$ \\
\hline $\mathrm{Ni}-\mathrm{Cad}$ & $\begin{array}{c}\text { Life cycle is quite high ( } 500 \text { cycles), easy } \\
\text { maintenance, value of internal resistance is } \\
\text { low so that make it possible charge and } \\
\text { discharge with high rate. }\end{array}$ & $\begin{array}{l}\text { There is memory effect to amount of } \\
\text { energy that released before, sensitive } \\
\text { when occurs overcharging. }\end{array}$ \\
\hline Li-on & $\begin{array}{l}\text { Longer battery cycle time, dimension of } \\
\text { battery relative small size, high efficiency } \\
\qquad(85-90 \%)\end{array}$ & $\begin{array}{l}\text { Electrolyte lateness LiFP6 has toxid } \\
\text { character and flammable, no strong } \\
\text { against hot temperatures, excess } \\
\text { recharge will reduce battery life. }\end{array}$ \\
\hline
\end{tabular}

TABLE II

CHARACTERISTICS OF CHEMICAL BATTERIES TYPE [12]

\begin{tabular}{|c|c|c|c|c|}
\hline Criteria & Lead Acid & Ni-Cad & Ni-MH & Li-on \\
\hline Self discharge rate & Very low & High & High & Moderate \\
\hline Overcharge tolerance & High & Moderate & Low & Very low \\
\hline Specific density (Wh/kg) & $25-35$ & $35-65$ & $40-100$ & $11-190$ \\
\hline Charging temperature ( $\left.{ }^{\circ} \mathrm{C}\right)$ & $0-25$ & $0-45$ & $0-45$ & $0-45$ \\
\hline $\begin{array}{c}\text { Cycle life (up to } 80 \% \text { of } \\
\text { initial capacity) }\end{array}$ & $200-300$ & $1000-1500$ & $750-1000$ & $500-1000$ \\
\hline Voltage per cell (volts) & 2 & 1,2 & 1,25 & 3,6 \\
\hline
\end{tabular}

A wet-type battery or lead-acid battery is an electric power generator that uses a chemical reaction of lead and sulfuric acid to generate electric current. In terms of battery maintenance, there are two types, namely the automotive battery, and deep cycle battery. From a construction perspective, the battery is divided into five groups. The group is the conventional wet batteries, hybrid batteries, calcium batteries, maintenance-free batteries, and sealed batteries [10]. In general, the classification of battery by its technology and construction is shown in Figure 1. 


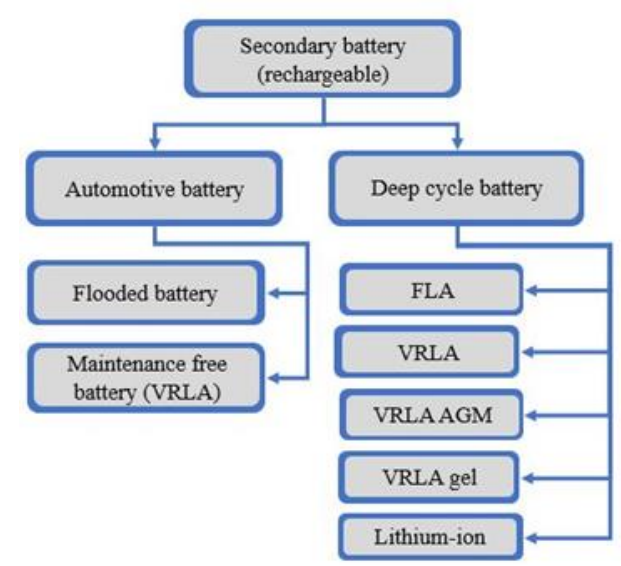

Fig. 1. Secondary battery (rechargeable)

B. Automotive Battery and Deep Cycle Battery

As shown in Figure 1, from an application perspective, the battery is divided into two groups: automotive and deep cycle batteries. An automotive battery is also known as a starting battery. This battery is designed to be able to produce large but short to start the engine of a vehicle. To start the engine requires a high electric current. After the engine starts, the battery breaks and is recharged again by the alternator. Most of the battery available on the market is the starting type. This battery is not suitable for electric vehicles.

A deep cycle battery is designed to generate stable energy (electrical current) and for a long time. This type of battery withstands repeated recharging and discharging cycles due to its construction using thicker plates. Deep cycle batteries are widely used in equipment that uses electric motors such as wheelchairs, forklifts, golf carts. This type of battery is also widely used for renewable energy applications as storage for electrical energy such as solar PV plants, wind turbines, and hydropower plants [10].

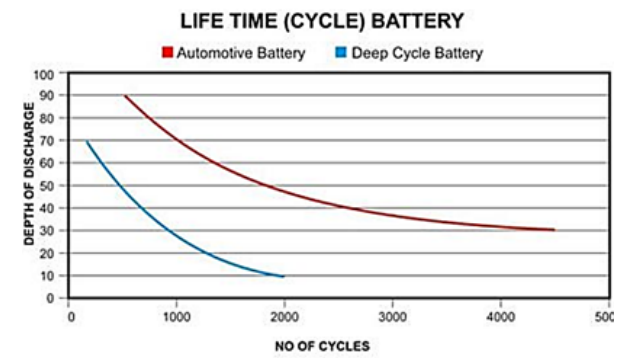

Fig. 2. Comparison of lifetime battery [11]

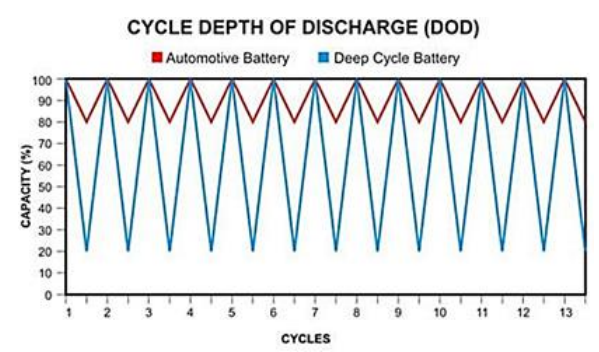

Fig. 3. Comparison of cycle depth of discharge [11]
The comparison between automotive batteries with deep cycle batteries as indicated by the chart lifetime (cycle) and the cycle depth of discharge is shown in Figure 2 and Figure 3. The automotive battery is made not to discharge for a relatively long time. The deep cycle battery is designed for discharge usage up to $80 \%$ of its capacity with a longer cycle.

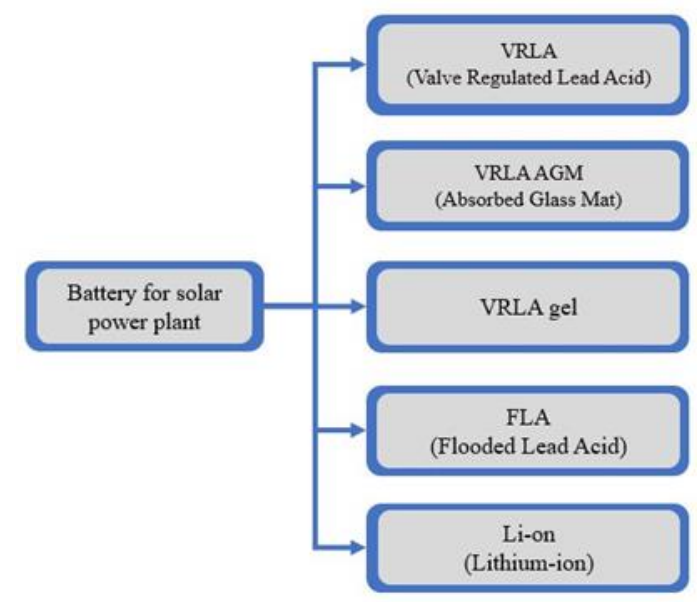

Fig. 4. Batteries for solar PV application

A deep cycle battery (VRLA) is solar PV battery systems designed to generate energy (electric current) in stable and relatively for a long time. This type of battery has the resistance to the cycle, often called cycle, charging (charge) and discharging (discharge) are repeated is also constant. Ideally, this type of battery can be used up to $80 \%$ of its nominal capacity. So the energy capacity that can be used is greater, without damaging and reducing the working life of the battery.

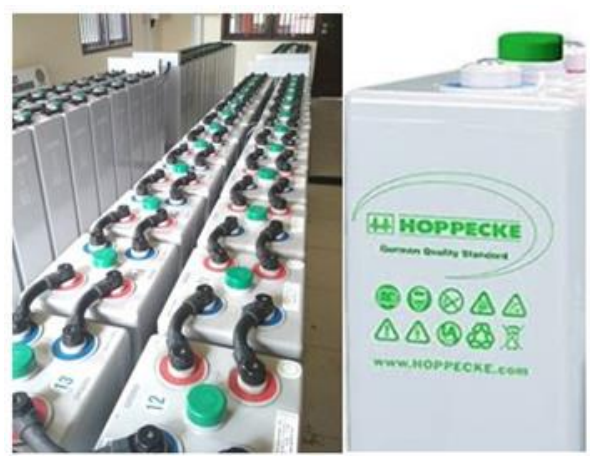

Fig. 5. Deep cycle battery

Figure 5 shows the installation of 96 units of deep cycle batteries to produce a $192 \mathrm{kVAh}$ capacity storage system on the smart microgrid system at Udayana University [4], [5]. 


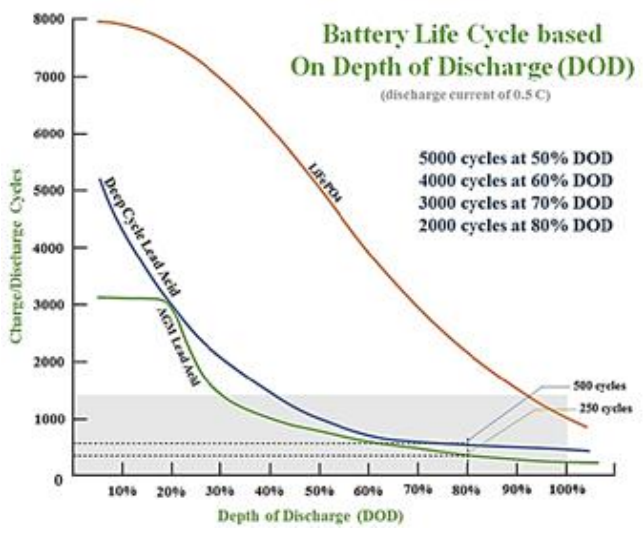

Fig. 6. Battery life cycle based on the depth of discharge [12]

Flooded Lead Acid (FLA) battery or often called wet cells or flooded battery. This is because the cells of the battery must be immersed in electrolyte fluid to function optimally. If the fluid level is below the limit then it must be added. Each cell of the battery has a valve for filling the electrolyte fluid [10].

Valve Regulated Lead Acid (VRLA) battery or Sealed Lead Acid (SLA) is also known as a dry battery. The battery is closed (sealed) hence the steam coming out of the battery is very little (occurring recombination) therefore no need to add liquid/ electrolytes during the life of the battery. Because the electrolyte does not decrease due to leaking or evaporation, this type of battery has a vent valve that only opens at extreme pressure to remove the gases generated by the chemical reactions. The battery is also known as maintenance-free batteries [10].

Absorbent Glass Mat (AGM) battery has a separator consisting of fiberglass that is placed between the cell plates. The purpose is to absorb electrolyte so that it is stored in the pores of the fiberglass. This fiberglass function similar to a towel that absorbs water when one end of the towel is immersed in a bucket filled with water [10].

VRLA gel battery has a liquid electrolyte that is mixed with silica sand so that it becomes thick like gelatin or pudding (gel). This gel functions as an electrolyte liquid. The VRLA gel battery should not be used in devices that require a high electric current supply (discharging) or are filled with high currents (charging) to prevent damage to the gel quickly [10].

A lithium-ion battery is a rechargeable battery. Inside this battery, ions lithium moves from the negative electrode to the positive electrode when released, and again when refilled. Battery Lithium-ion taking lithium intercalation compounds as electrode materials, unlike metallic lithium is used in lithium non-rechargeable. The lithium-ion battery is generally found in consumer electronics. It is the most popular type of rechargeable battery for portable electronic equipment because high energy densities, no memory effect, and experience slow charge loss when not in use. Lithiumion Battery (LIB) is also used by the military, electric vehicles, and aerospace industries [13].
Several studies have sought to improve traditional LIB technology, focusing on intrinsic energy density, durability, cost, and safety. In terms of price, lead-acid batteries are the most widely used battery for solar PV systems. The deep cycle VRLA gel battery is the most expensive type of battery in the lead-acid class due to material and production costs [14]. However, it is still much cheaper than lithium batteries [13].

In terms of the life cycle, the VRLA AGM and gel battery types have a fairly good cycle up to more than 800 cycles or the equivalent of more than 2 years of use [13]. For treatment, the type of flooded should always be done. The flooded type should not be placed carelessly, because the liquid can leak. The VRLA type is easier to maintain because it does not need to be filled with electrolyte. For disposal, lead-acid battery has dangerous ingredients. Therefore, it is necessary to carry out appropriate waste treatment to protect the environment from pollution [13].

The advantages of lithium-ion batteries are that they are lighter than other rechargeable batteries of the same weight. It has a very high energy density, so a lot of energy can be stored. It is environmentally friendly and has high efficiency. While the drawbacks of lithium-ion batteries are that they have a short lifetime of 2 to 3 years from the date of manufacture and sensitive to high temperatures, and high initial price [13].

\section{Parameters in Choosing Battery for Solar PV}

The important parameters in choosing a battery for solar $\mathrm{PV}$ plants to suit the needs of the PV design are presented in Figure 7 below.

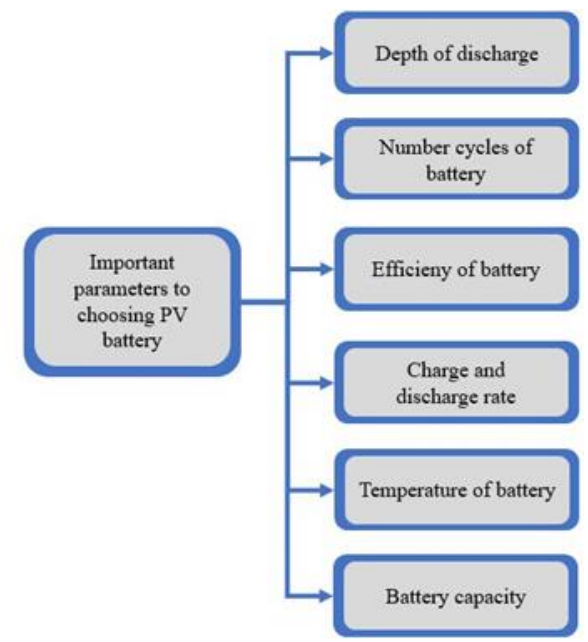

Fig. 7. Parameters for choosing battery for solar PV [15], [16], [17]

The depth of discharge is the amount of charge /energy released or consumed by the battery. DoD is expressed as a percentage of the nominal capacity of the battery. For example, DoD $80 \%$ means that the battery has released its charge $80 \%$ from its $100 \%$ nominal capacity. Thus, there is a condition the battery only has a charge of about $20 \%$, which is also called the SOC or state of charge. The higher 
the $\mathrm{DoD}$, the shorter the life of the battery [18]. In the calculation, the battery is expressed by 2 DoD numbers, namely maximum DoD and daily DoD. If maximum DoD is reached, the charge controller will disconnect the battery from the load (cut-off). Meanwhile, daily DoD is the average DoD limit that will be achieved in each normal cycle.

One battery cycle is one time the complete process consisting of one discharge and one charge. Battery life is usually expressed as the number of battery cycles. For example, if a battery has a lifespan of 1800 cycles, and operated one cycle per day, the battery life is $1800 /(1 \times 365$ days) equals to 4,9 years. But if two cycles per day, the battery life drops to 2,5 years.

Losses in the battery occur due to internal resistance which dissipates the electrical energy into heat during charging and discharging. The lead-acid battery for solar PV applications has an efficiency of $85-80 \%$ with a total cycle of 1500-5000 [19]. The efficiency in one cycle is called the round trip efficiency.

The charge rate or discharge rate is a number that states the time that required batteries in clicking the contents then make a charge. The discharge rate is symbolized by Cxx and generally, the battery is standardized with a rate of $\mathrm{C} 20$ [9], meaning how much a battery current can discharge in 20 hours. The greater the discharge rate, the smaller the capacity of the battery. The rate of charging and discharging will determine efficiency as well, the faster rate lowers the efficiency, this is because the electric current that flows will increase.

Temperature greatly affects battery performance. The higher the battery temperature, the more capable the battery is to work at its maximum capacity. However, when operates at higher temperatures it will cause premature aging. The ideal battery temperature is around $20^{\circ}-25^{\circ} \mathrm{C}$ [20].

Battery capacity is expressed in Ah or ampere-hours. The greater capacity of a battery, the larger the battery dimension, and the more expensive the battery is [21], [22]. For example, if a solar PV uses a battery with a capacity of 2000 Ah with a voltage of 2 volts then the battery can store a charge of $2000 \mathrm{Ah} \times 2 \mathrm{~V}$ or $4 \mathrm{kWh}$. The criteria for selecting batteries for solar PV are presented in Table 3.

TABLE III

BATTERY CRITERIA FOR SOLAR POWER PV [15], [16], [17]

\begin{tabular}{|l|l|}
\hline \multicolumn{1}{|c|}{ Criteria } & \multicolumn{1}{c|}{ Description } \\
\hline Battery & Deep cycle \\
\hline Regulating valve & Valve regulator lead acid \\
\hline Electrolyte & Wet, gel, absorbent glass mat \\
\hline Electrode & Tubular \\
\hline Voltage per cell & 2 volt DC \\
\hline Capacity per cell & Minimum $1800 \mathrm{Ah}$ at C20 discharge \\
\hline Number of cell & Minimum 2000 at DoD $80 \%$ \\
\hline Battery capacity & Able to days of autonomy for 2 times periods of operation \\
\hline Depth of discharge & Maksimum $80 \%$ \\
\hline
\end{tabular}

\section{MATERIAL AND METHOD}

This research reviews the development of batteries for the solar PV application in Indonesia. The review is carried out through a survey on solar PV plant batteries using reliable resources of information such as the manufacturer's website, battery datasheet, e-commerce, and battery research conducted in Indonesia. The schematic of the research methodology is shown in Figure 8.

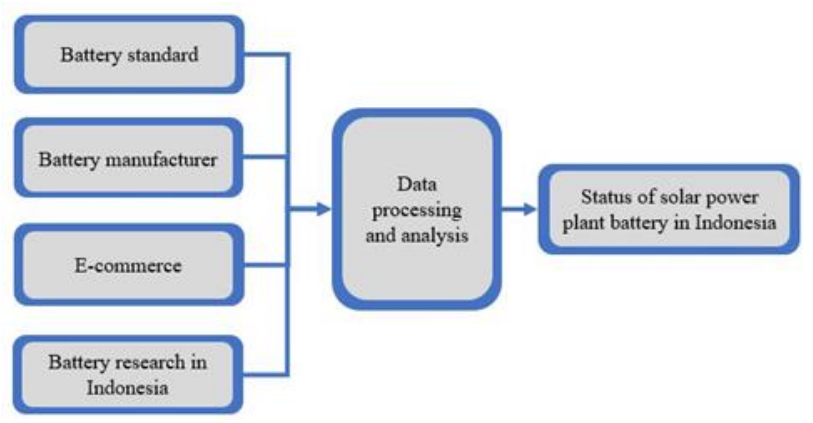

Fig. 8. Schematic research methods

Step 1 is to review battery standards. This step identifies national and international standards for battery development or manufacture. Step 2 is to review the survey battery manufacturer in Indonesia. Step 3 is a survey of battery available in Indonesia. Step 4 is to review the literature or research on batteries and their applications in Indonesia.

Parameters used in the discussion of this study are technical specifications such as battery voltage, battery capacity (Ah), Depth of Discharge (DoD), State of Charge (SoC), battery dimensions, battery weight, battery technology, battery standards, and price. The data is sourced from battery manufacturers, technical datasheets, scientific publications, and e-commerce in Indonesia and abroad. And finally, data is processed and analyzed to get information about the status of the batteries for solar PV applications in Indonesia.

\section{RESUlt AND DisCUSSION}

The survey on battery for solar PV applications resulted in a database consisting of 361 batteries. The database is grouped by manufacturer, battery technology, battery capacity, battery voltage, depth of discharge, state of charge, weight, dimensions, and battery price. The database containing all the batteries and technical specifications reviewed in this study is arranged in a table and can be obtained by contacting the author.

\section{A. Battery Standards in Indonesia}

The development standard for battery in Indonesia begins with the issuance of the National Standard of Indonesia (SNI) on battery technology and its testing. Starting with the SNI on capacity and secondary battery cycles in 2000 which was then followed by other standards including lithium-ion battery standards. The list of standards related to the battery is shown in Table 4 [23], [24]. 
TABLE IV

BATTERY STANDARDS IN INDONESIA

\begin{tabular}{|c|c|c|}
\hline No & Standard & Type of Testing \\
\hline 1 & SNI 04-6392-2000 & Capacity and secondary battery cycles \\
\hline 2 & SNI 0038-2009 & Lead acid battery for 4 wheels vehicle or more \\
\hline 3 & SNI 4326:2013 & Lead acid battery for $\mathrm{L}$ category vehicle \\
\hline 4 & SNI 04-2051.1-2004 & Primary battery generally \\
\hline 5 & SNI 04-2051.2-2004 & Physic spesification and electrical of primary battery \\
\hline 6 & SNI IEC $62660-1: 2017$ & $\begin{array}{l}\text { Secondary ion lithium cell for mover electric vehicle: } \\
\text { performance testing }\end{array}$ \\
\hline 7 & SNI IEC 62660-2:2017 & $\begin{array}{l}\text { Secondary ion lithium cell for mover electric vehicle: } \\
\text { reliablitiy and abuse testing }\end{array}$ \\
\hline 8 & IEC $61427-1: 2013$ & Requirements of secondary battery \\
\hline 9 & IEC 60896-22 & Replacement of utility \\
\hline 10 & IEEE $1188-2005$ & Maintenance, testing and battery replacement \\
\hline 11 & ISO 12405-3 & Battery safety \\
\hline & ISO $12405-1$ & \multirow{3}{*}{ Battery performance } \\
\hline 12 & ISO $12405-2$ & \\
\hline & ISO $12405-4$ & \\
\hline 13 & IEC 62660-3:2016 & $\begin{array}{l}\text { Spesification of safety testing and battery system of } \\
\text { lithium traction. }\end{array}$ \\
\hline 14 & ISO 18243:2017 & $\begin{array}{l}\text { Testing spesification and requirements of safety for } \\
\text { lithium-ion battery system }\end{array}$ \\
\hline
\end{tabular}

Based on Table 4, various battery standards in Indonesia has been released. Many of the standards are derived from international standards.

\section{B. Battery Technology in Indonesia}

In terms of battery technology, five battery technologies are circulating in the domestic market. They are FLA, VRLA, VRLA AGM, VRLA gel, and li-on batteries. From the 361 batteries surveyed, the composition of the battery according to their technology is shown in Figure 9.

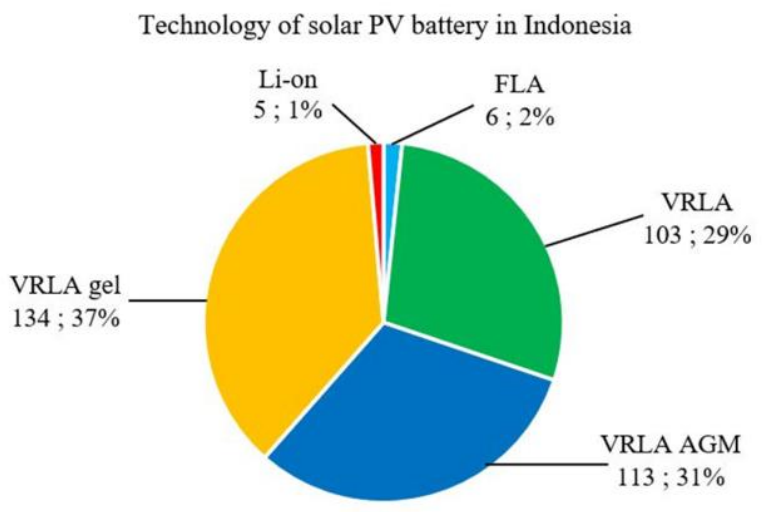

Fig. 9. Battery technology in the Indonesian market
Figure 9 shows the most widely available battery technology is VRLA gel. There are 134 VLRA gel batteries of various specifications. Whereas the least available battery technology is li-on. This is because lead-acid has energy per unit cost lower than the li-on [25]. Also, lead-acid is the first battery technology so that it is a well-established technology and has been widely used in many electrical systems [26]. The VRLA gel has a longer service life and better cycle capacity than VRLA AGM [27].

\section{Battery Voltage}

In terms of the battery voltage, there is five battery voltage available in the domestic market. The voltages are $2,4,6,8$, and 12 volts. Figure 10 shows the voltage level available in the market.

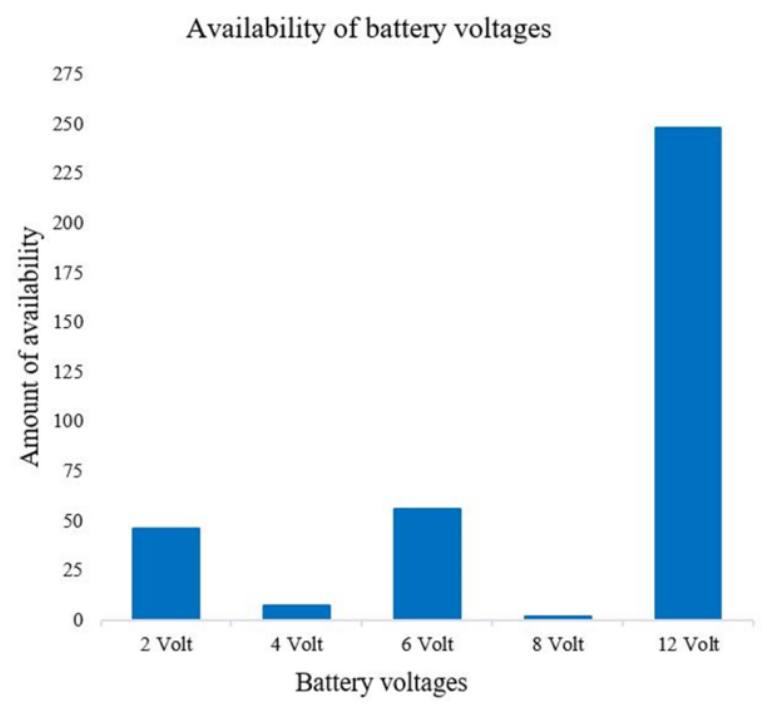

Fig. 10. Availability of battery voltage

Figure 10 shows the most available battery voltage is 12 volt. There are 248 batteries with $12 \mathrm{~V}$ voltage. Whereas the least available voltage is 8 volts. This is because the 12-volt battery applies to a wider industry such as wind, solar PV plant, UPS, cable TV, telecommunications, health, security systems, emergency light, and electric vehicles [28].

\section{Battery Capacity}

In terms of battery capacity, 91 different capacities have been surveyed. The capacity ranging from $1 \mathrm{Ah}$ to 3000 Ah. The full range of battery capacities is shown in Figure 11 . 


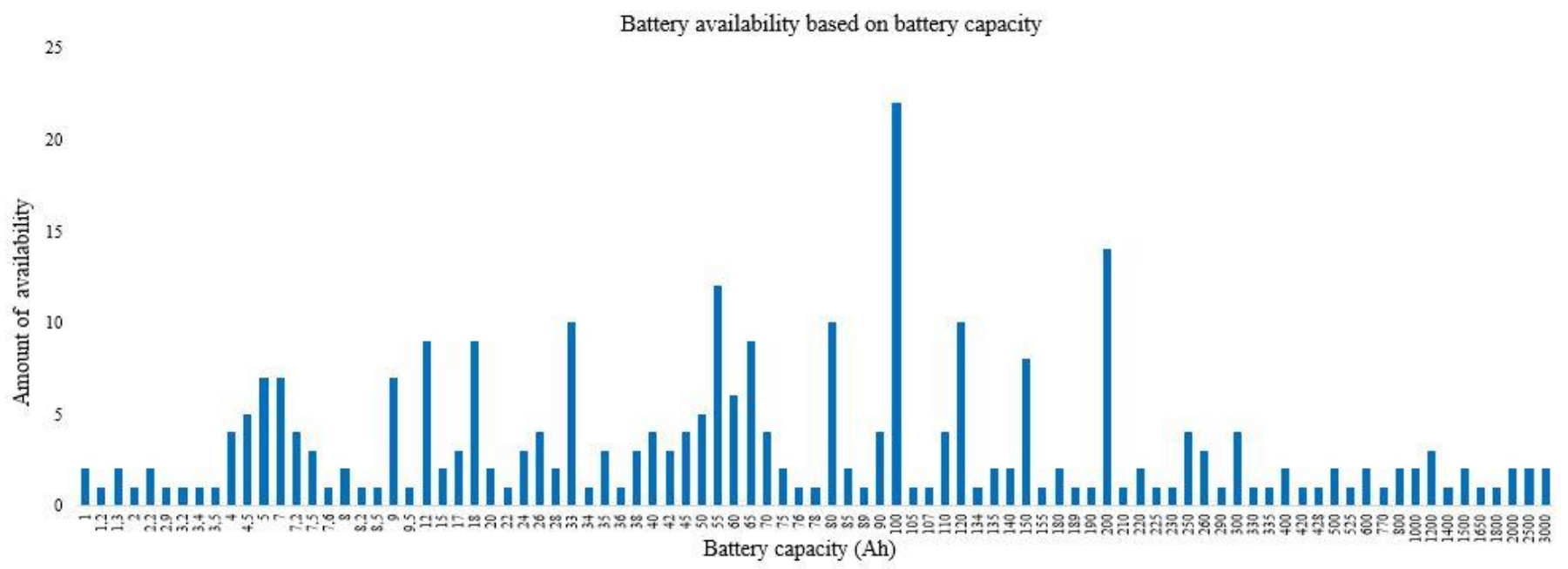

Fig. 11. Range of battery capacity available in the country

As shown in Figure 11, the most widely available is a battery with a capacity of $100 \mathrm{Ah}$. There are 22 batteries with 100 Ah capacity. Battery with low capacities between 1 to $10 \mathrm{Ah}$ and battery with large capacities between 190 to 1650
Ah are available but not very common. This is perhaps due to their limited application. Applications that require high capacities above $1000 \mathrm{Ah}$ are in the telecommunication, UPS, military, and power plant storage [28].

\section{Relation between price of battery with battery capacity}

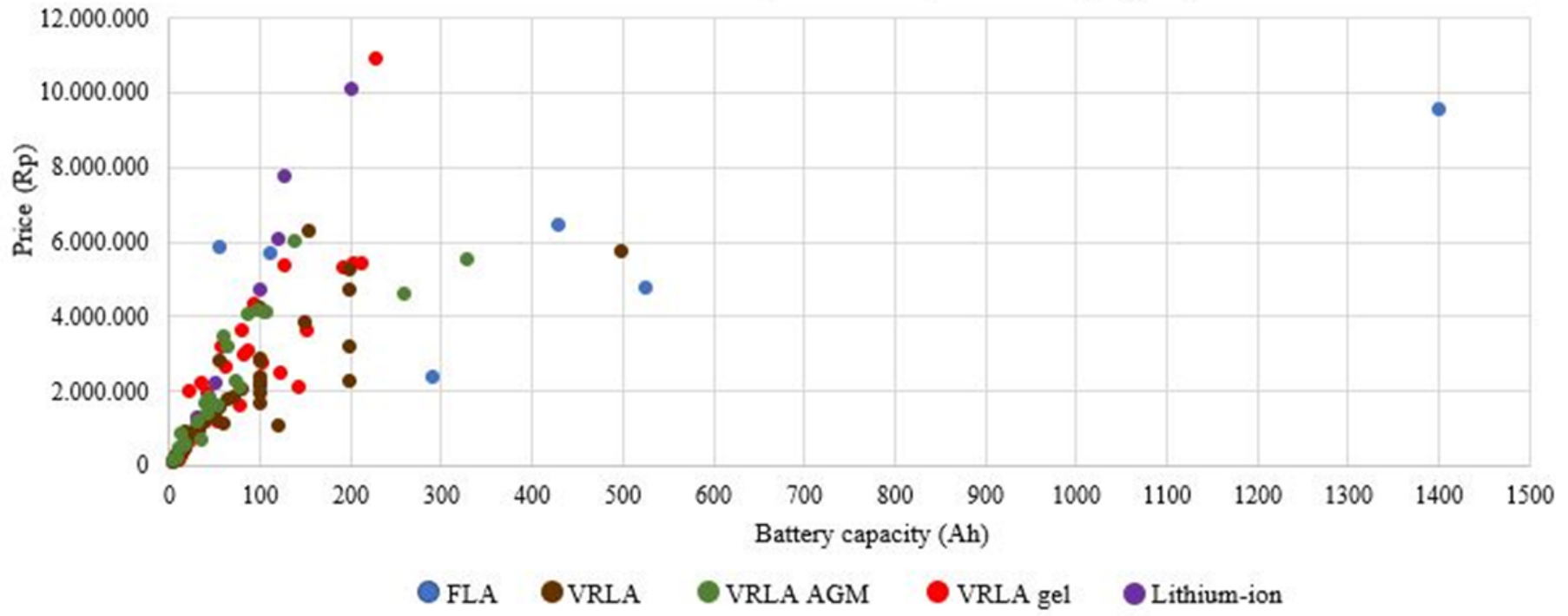

Fig. 12. The relation between battery capacity and cost

Figure 12 shows the relation between the capacity and cost of batteries. Li-ion battery has the highest cost compared to VRLA gel and VRLA with the same capacity. Lithium- ion batteries have a higher energy cost per unit than lead-acid batteries [21], [25]. 


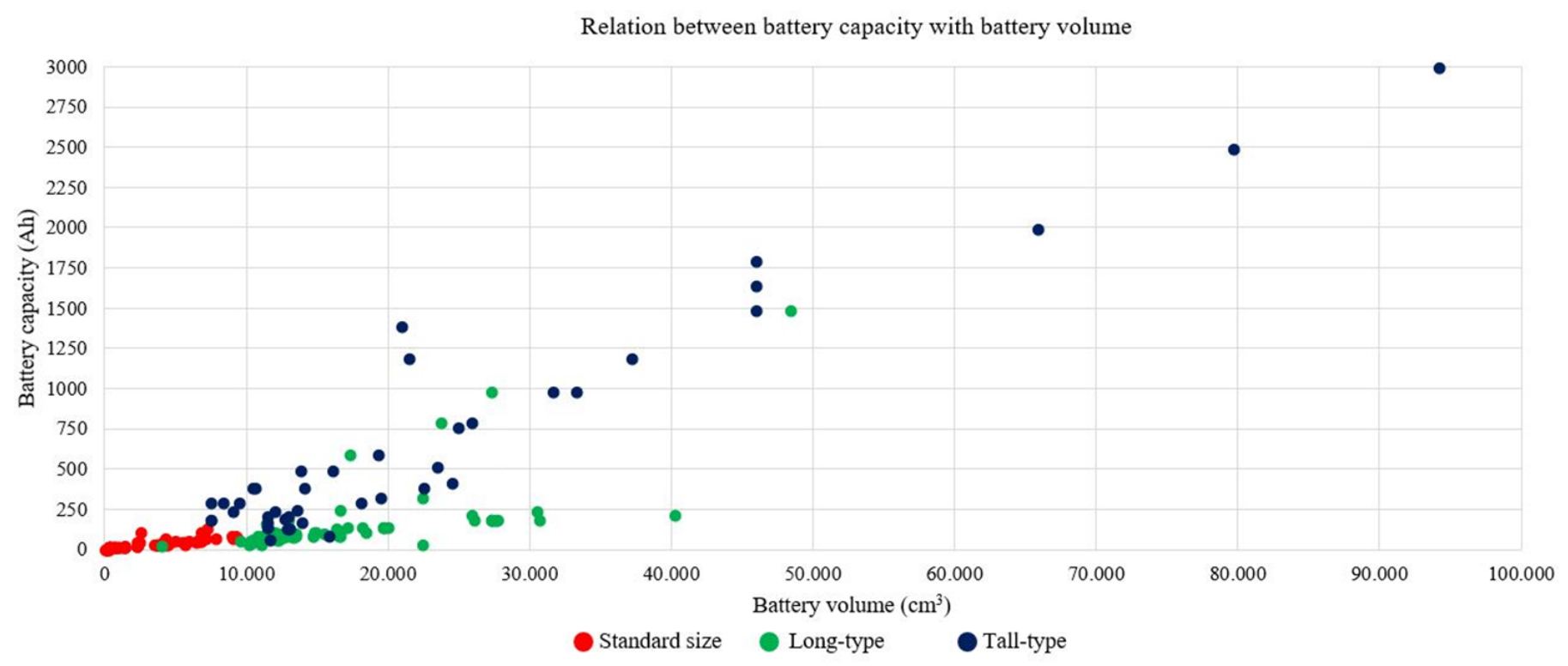

Fig. 13. The relation between battery capacity and volume

Figure 13 shows the relation between battery capacity and overall volume. The greater the volume of the battery so is its capacity. The capacity of the battery is directly proportional to the amount of electrode material and electrolytes in the battery. A large physical battery has a large capacity and vice versa [22]. An example of the battery dimensions is shown in Figure 14.

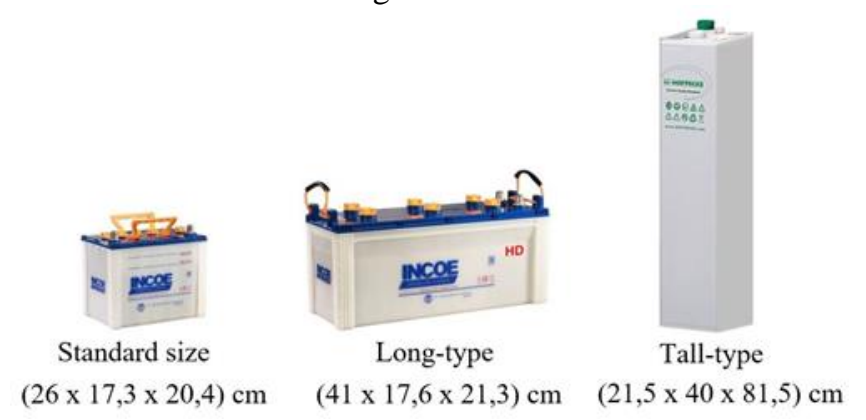

Fig. 14. Example of battery dimension [11], [29]

\section{E. Battery Manufacturers in Indonesia}

If the market for electric vehicles and renewable energy power plants grow in the future, the need for a secondary battery that has high specific capacities and energy densities is necessary. Naturally, the battery industry in Indonesia will also focus on the secondary battery with the starting, lighting, and ignition types [8]. Table 5 lists battery manufacturers in Indonesia. There are several battery manufacturers for solar PV plant applications such as PT. Indobatt, PT. Yuasa Battery and PT. Nippers. However, there are also demands for batteries that are not yet produced domestically. In such a case, the overseas manufacturers will supply the demands from company branches located in other countries. It appears they have no plan yet to build a factory in Indonesia. This is why the price of batteries is still relatively expensive [8].
TABLE V BATTERY MANUFACTURER IN INDONESIA [30]

\begin{tabular}{|c|c|c|c|}
\hline No & Company & Product & Information \\
\hline 1 & PT. Indobatt & NGS, NEO, Volcano & $\begin{array}{l}\text { Factory location at Krian, East Java. Battery } \\
\text { production for cars and motorcycles. }\end{array}$ \\
\hline 2 & $\begin{array}{l}\text { PT. Gramitama } \\
\text { Battery }\end{array}$ & $\begin{array}{c}\text { GBI, GS Premium, OSAKA, } \\
\text { Yama }\end{array}$ & $\begin{array}{l}\text { Factory location at Sidoarjo, East Java. Battery } \\
\text { production for cars and motorcycles. }\end{array}$ \\
\hline 3 & PT. Yuasa Battery & $\begin{array}{c}\text { Yuasa Pafecta, Yuasa } \\
\text { Maintenance Free, Yuasa } \\
\text { Hybrid, Yuasa Yumicom, Yuasa } \\
\text { VRLA, Yuasa Super MF } \\
\end{array}$ & $\begin{array}{l}\text { Factory location at Tangerang, Banten. Battery } \\
\text { production for cars and motorcycles. }\end{array}$ \\
\hline 4 & $\begin{array}{l}\text { PT. International } \\
\text { Chemical Industry }\end{array}$ & $\begin{array}{l}\text { ABC Alkaline, ABC Super } \\
\text { Power, ABC New Special, ABC } \\
\text { Dry Cell, ABC Economy }\end{array}$ & $\begin{array}{l}\text { Factory location at Cengkareng, Banten. Dry } \\
\text { bartery (dry cell) production for very low } \\
\text { voltage necessity. }\end{array}$ \\
\hline 5 & $\begin{array}{l}\text { PT. World Star } \\
\text { Battery Indonesia }\end{array}$ & ws Worldstar & $\begin{array}{l}\text { Factory location at Surabaya, East Java. } \\
\text { Battery production for cars and motorcycles. }\end{array}$ \\
\hline 6 & $\begin{array}{l}\text { PT. Leoch Battery } \\
\text { Indonesia }\end{array}$ & $\begin{array}{l}\text { LP, LPX, LHR, LPL, LPF, } \\
\text { DJW, LPG, LPG-FT, LPC }\end{array}$ & $\begin{array}{l}\text { Factory location at Daan Mogot Tangerang } \\
\text { Banten. Battery application for electric vehicle, } \\
\text { motorcycles and cars, UPS and others. PT. LBI } \\
\text { also produce others product like charger, power } \\
\text { inverter, golf car. }\end{array}$ \\
\hline 7 & PT. Nippress, Tbk & NS & $\begin{array}{l}\text { Factory location at Bogor, West Java. Battery } \\
\text { application for cars, motorcycles, golf car and } \\
\text { battery industry. }\end{array}$ \\
\hline
\end{tabular}

In 2019, Indonesia is in second place as a vehicle manufacturer in Southeast Asia [31]. Meanwhile, as an effort to reduce emissions from the transportation sector, as the Indonesian government has targeted $20 \%$ of electric vehicles by 2025 by producing electric vehicles battery-based. In this context, Indonesia is a country with the largest nickel reserves in the world [32], and nickel is one of the important components in the manufacture of batteries. To support the plan, Indonesia has begun with plans to build factories in the country. The government plans to build four battery factories with foreign investment from China. The locations of the factory are (1) Morowali Central Sulawesi, (2) Weda Harbor North Maluku, (3) Obi Island North Maluku, and (4) Pomalaa South Sulawesi [33]. The distribution of existing battery and future factories are shown in Figure 15. The blue dots are the factories that are already in operation and the orange dots are the plan for new factories. 


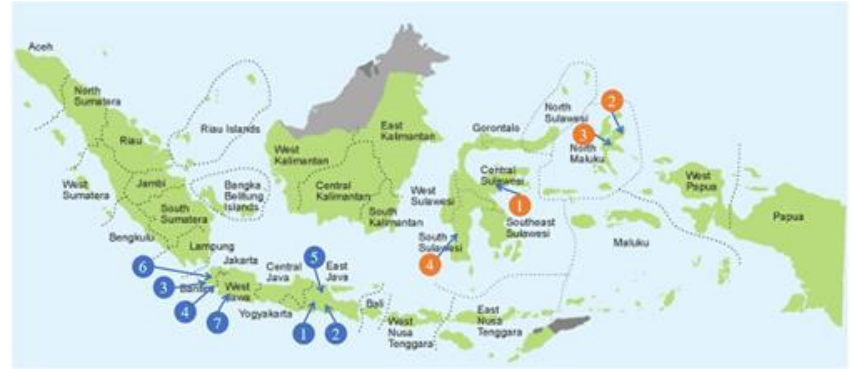

Fig. 15. Map of battery factory location [34]

\section{F. Designing Battery Capacity}

In the solar PV system, the batteries will be arranged in series and parallel to produce a battery system with a certain voltage and capacity as needed. The batteries are connected in series to obtain higher voltage and are connected in parallel to obtain higher capacity. Figure 16 shows a battery energy storage system for the smart microgrid installed in Udayana University Bali. The BESS has a capacity of 192 $\mathrm{kVAh}$. The BESS is made of four battery banks. Each bank consists of 24 batteries connected in series. And finally, the four banks are connected in parallel to obtain a battery capacity of $192 \mathrm{kVAh}$.

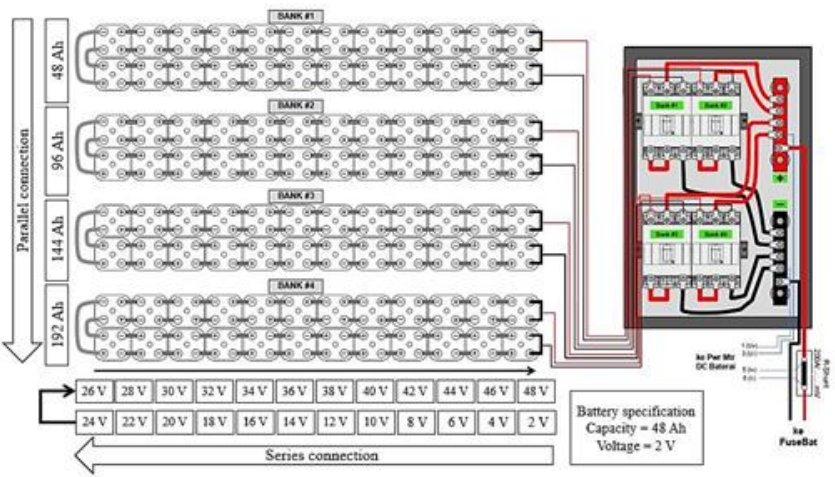

Fig. 16. Battery configuration in microgrid Udayana University [5]

\section{G. Battery Recycling In Indonesia}

Several regulations have been released by the government to handle battery waste. Government Regulation \#18/1999 and \#85/1999 concerns with the management of Hazardous and Toxic Waste. It is stated that wet cell battery waste is categorized as hazardous and toxic waste from specific sources [35]. Hazardous waste can be generated if a battery is not needed or cannot be used or cannot be recycled. A battery normally contains $\mathrm{PbO}_{2}$ and $\mathrm{Pb}$. Both of these compounds are used as battery housing. Also, the battery will contain liquid waste which consists of sulfuric acid as used as an electrolyte solution [36].

Government Regulation \#55/ 2019 on the acceleration of the battery-based electric vehicles program, in Chapter VI of environmental protection, the handling of waste electric vehicle batteries must be done through recycling and/or waste management [37]. Another regulation is the Decree of the Minister of Environment \#51/1995 on Liquid Waste Quality Standard for Industrial Activities [38]. Without the management and the proper processing, the disposal of used batteries for a motor vehicle can result in contamination of the environment such as pollution of soil and groundwater caused by the electrolyte solution and heavy metals contained in batteries such as lead that can harm human health and other living organisms [39].

On a practical level, Respati and Damanhuri's (2009) discussed frameworks to overcome the environmental pollution caused by batteries. The frameworks begin with the owner of used vehicle batteries sell their used batteries to informal recyclers such as scavengers, junk dealers, stalls, to used battery collectors. At the stalls and collectors, the weight of the used battery is measured to determine the weight and composition of the material of the battery. The ultimate goal is a recycling plant where tin is melted and turned into tin bars as a raw material for making new batteries [40].

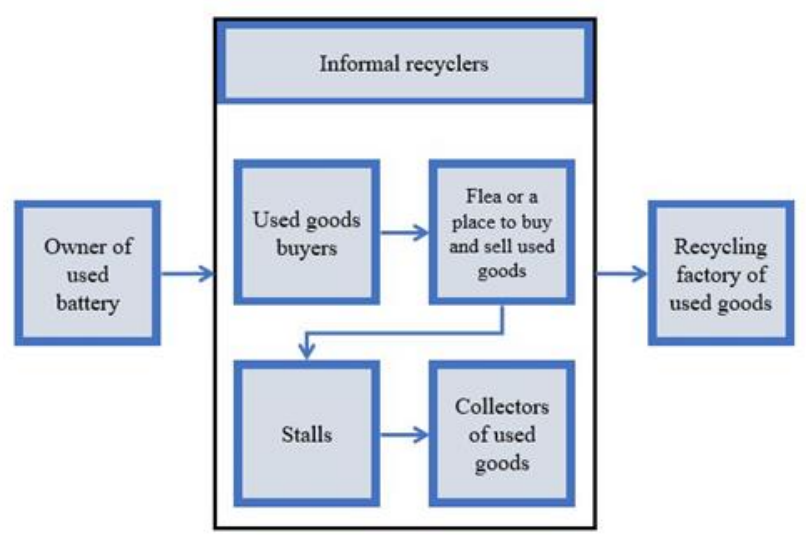

Fig. 17. Schematic of battery waste management [40]

Recycling is an effective way to avoid environmental pollution and reducing the volume of motor vehicles used batteries in landfills [41]. The reduction of lead from the used batteries cannot be separated from the role of the informal sector recyclers. The informal recyclers are generally smallscale, do not have a business license, and still use simple technology [42].

\section{H. Research on Battery in Indonesia}

This section discusses the research and development of batteries carried out in Indonesia. Data were obtained by reviewing scientific publications on batteries conducted by researchers in or from Indonesia.

Utomo (2013) reported a study on the performance test of deep cycle batteries as a component of a solar-powered LED street lighting system in which he carried out a discharging and charging test. The two performance tests to find out how long the battery can provide electrical power to turn on the LED lights for 11 hours per day. The results showed the discharge time of the battery connected to the polycrystalline and monocrystalline solar modules was 228 minutes (38 hours) and 2370 minutes (39,5 hours), respectively. Meanwhile, the charging time for the battery connected to the polycrystalline and monocrystalline solar modules was 1590 minutes (26,5 hours) and 2130 minutes (35,5 hours), respectively. It was concluded deep-cycle batteries can power the LED streetlights for more than three days [43]. 
Jauharah (2013) reported on the analysis of electricity produced by fruit and vegetable waste as alternative energy for bio-batteries. The researchers aimed to determine the value of the current and voltage strength produced by the biobattery of citrus fruit, banana, tomato, chili, and carrot waste to make an optimal bio-battery. The results showed that the bio-battery capable of powering the LED light is citrus fruit waste with 75 hours [44].

Yulianti et al. (2013) reported on the fabrication of a solid polymer electrolyte material based on montmorillonite chitosan nanocomposites for battery applications. This study aimed to determine the optimal composition of chitosan montmorillonite and $\mathrm{LiCIO}_{4}$ to obtain the best characteristic membrane. The results of X-ray diffraction analysis showed an intercalation process of chitosan polymer into montmorillonite [45].

Utomo (2015) reported research on the performance of deep cycle batteries with inverters in a solar PV plant system. Deep cycle batteries and inverters are tested through a series of battery charge-discharge tests. The results showed the tested batteries have the same capacity and characteristics as the technical data from the battery manufacturer, while the inverter test results show that the efficiency of the inverter is still lower than the technical specifications of the manufacturer [46].

Alfith (2015) reported on battery configuration in renewable energy generators. This study discusses the design and management of tools developed with a Visual Basic (VB) software to increase system reliability and comfort. The experimental results showed the advantages of this design and performance approach provide an excellent solution for renewable energy applications [47].

Farizy (2016) reported on the design of monitoring the state of charge of a battery in an electric car charging station based on Fuzzy Logic by considering temperature, charge, and discharge process on the battery to obtain an accurate state of charge so that the battery does not break quickly [48].

Amri (2016) reported photovoltaic pulse charges for energy storage configurations through the concept of change management in standalone PV systems. This study aimed to maintain the balance of the power in PV so that it continues to supply energy at the maximum point. Comparison of the results of the simulation methods MPPT of $0.053 \%$ and a constant voltage of $0.024 \%$ in the duration of charging for 6 seconds at iradian $1000 \mathrm{~W} / \mathrm{m}^{2}$ and temperature of $25^{\circ} \mathrm{C}$ [49].

Pangemanan (2017) reported an experimental study of a discharge test on a $12 \mathrm{~V}$ battery connected to a DC motor. The results showed the battery meets BKI regulations with an estimated maximum power of 869,4 watts [50].

Simanjuntak et al. (2017) reported on the design of an automatic control system and battery condition safety in a microcontroller-based power plant system. The study discussed a microcontroller-based battery control and observation system that will provide information in the form of current, voltage, temperature, and indicators if one of the batteries is released. The results showed that the automatic control system and monitoring via a computer screen can be implemented using a microcontroller. the microcontroller can work automatically so that it makes it easier for operators to monitor DC systems using batteries compared to conventional monitoring [51].

Rizkyanto (2018) reported on the analysis of the effect of temperature on the durability of battery containers to increase service life in the maintenance-free battery. A comparative study of the maintenance-free battery container NX100-S6 of brand A and brand B. The results of battery container brand $\mathrm{B}$ showed the temperature. On the wall of the battery, the container was originally $75^{\circ} \mathrm{C}$. The process of redesigning the battery container brand $\mathrm{B}$ was carried out by adding foam and boxes as container linings. The addition of these boxes can lower the temperature of the battery container wall by $45^{\circ} \mathrm{C}$ which makes the temperature of the battery container wall down to $30^{\circ} \mathrm{C}$ [52].

Astriani et al. (2018) reported on balancing the state of charge of lead-acid batteries in the battery management prototype. In this research, a prototype of a battery Battery Management System (BMS) was developed for four leadacid batteries with a capacity of $100 \mathrm{Ah}$. The BMS function is to balance the charge through observation of the SoC using the Coulomb counting method. Since the charge balance of each battery is kept optimal, then the battery discharge duration can be increased longer [26].

Taufik et al. (2019) reported on the estimation of the state of charge regulated lead-acid deep cycle $12 \mathrm{~V}$ batteries with the Coulomb counting method. The results showed that this battery was effective for use with a discharge limit of $>19 \%$. The recommended maximum battery usage limit up to $20 \%$ of capacity. If the battery discharge is $<19 \%$, the charging capacity will be longer and the battery reliability will decrease [53].

Zainuri et al. (2019) reported that the VRLA battery state of health estimation based on charging time estimates the SoH value of a battery based on charging time measurements. The results indicated different charging times. The analysis was carried out to determine the correlation between the SoH battery and the charging period. The correlation between healthy and unhealthy battery charge-discharge times can be developed into a battery charger with the main advantage of not requiring any sensors for data acquisition [54].

Mufidah (2019) reported on the estimation of the state of charge on VRLA batteries with a polynomial regression method and to compare the estimated SOC and measurements on VRLA batteries. On a 3 Ah battery with a SOC $80 \%$, it can last 5,2 hours with a capacity stated on the nameplate and with a real battery capacity of 2,05 Ah. So the battery capacity has decreased by about $31,97 \%$. On a 5 Ah battery with a SOC of $80 \%$, the battery can last for 6,45 hours and with real capacity of 4,21 Ah. So, the battery capacity has decreased by $15,8 \%$. And on 7 Ah battery with a SOC of $80 \%$, the battery can last 7,2 hours, with a real battery capacity of $6,55 \mathrm{Ah}$. So, the battery capacity has decreased by about 6,43\% [55].

Sugeng and Saputra (2019) reported on estimating the state of charge on a solar PV plant battery using Simulink. The results showed the battery works in the SOC range of $30 \%$ for the lower limit and $90 \%$ for the upper limit, assuming the battery is a new battery that has not experienced many charges and discharge cycles [56]. 
Akhinov and Handaya (2019) reported on a battery charge control system in solar cell-based street lighting. This study aimed to design and implement a battery charge control system for solar cells-based streetlights. With the proposed control system, solar PV can provide up to $78 \%$ power efficiency and up to $94 \%$ efficiency in lamp use [57].

Rochmawati (2020) reported on predicting lead-acid battery capacity using the Extreme Learning Machine method. The estimation used two validation techniques, namely holdout validation, and cross-validation. The results showed cross-validation was better than holdout validation because the cross-validation data set is randomly changed to a subset according to the value [58].

Based on the literature discussed in this subsection, it is shown battery research in Indonesia has encompassed a wide range of battery from research on new bio-material, various performance tests, and including estimation of battery operation status using advanced computing techniques.

\section{IV.CONCLUSIONS}

This article has reviewed the availability of batteries for solar PV applications in Indonesia. There are 361 batteries available of various technologies such as FLA, VRLA, VRLA gel, VRLA AGM, and li-on. The most widely available battery is VRLA gel, while the least is li-on. Battery voltages range from 2 to 12 volts with the most widely available in the 12-volt battery. In terms of capacity, batteries are available from 1 to $3000 \mathrm{Ah}$ and the most are batteries with a capacity of $100 \mathrm{Ah}$

Standards on the battery have been released, but the standard on methods or procedures for recycling or its waste management is still limited. Therefore, it is necessary to develop standards for battery recycling to avoid environmental problems when the amount of unused battery becomes large in the future.

The current research in the battery field demonstrated the wide scope of the national battery researches. In the future, more researches are required and including research on recycling and waste management of batteries as the application of battery energy storage system will expand on only for solar PV application but also electric and conventional vehicles, and other applications, especially as the government plan to build battery factories in the country.

\section{REFERENCES}

[1] Perpres Republik Indonesia Nomor 22 Tahun 2017 Tentang Rencana Umum Energi Nasional.

[2] Aditya Nugraha, I.M., Giriantari, I.A.D., Kumara, I.N.S. 2013. Studi Dampak Ekonomi dan Sosial PLTS Pedesaan Terhadap Masyarakat Desa Ban Kubu Karangasem. Prosiding Conference on Smart-Green Technology in Electrical and Information Systems. Bali 14-15 November 2013. A-010

[3] Putra, B.A., Sukerayasa, I.W., Partha, C.G.I. 2020. Perancangan Sistem Pompa Air dengan Memanfaatkan PLTS $20 \mathrm{kWp}$ Desa Tianyar Tengah. E-journal Spektrum. Vol 7, No. 1.Hal 54-61.

[4] Wicaksana, M.R., Giriantari, I.A.D., Kumara, I.N.S. 2019. Unjuk Kerja Pembangkit Listrik Tenaga Surya Rooftop $158 \mathrm{kWp}$ pada Kantor Gubernur Bali. E-journal Spektrum. Vol. 6, No. 3. Hal 107113.
[5] Gunawan, I.N., Kumara, I.N.S., Irawati, R. 2019. Unjuk Kerja Pembangkit Listrik Tenaga Surya $26,4 \mathrm{kWp}$ pada Sistem Smart Microgrid UNUD. E-journal Spektrum. Vol 6, No. 3. Hal 1-9.

[6] Kumara, K.V., Kumara, I.N.S., Ariastina, W.G. 2018. Tinjauan Terhadap PLTS 24 KW Atap Gedung PT Indonesia Power Pesanggaran Bali. E-journal Spektrum. Vol 5, No. 2. Hal 26-35.

[7] Syahni, D. 2016. Pengembangan Listrik Tenaga Surya Masih Terkendala, Mengapa ?. Retrieved August 13, 2020. From : https://www.mongabay.co.id.

[8] Budiman, A.H. 2013. Kajian Roadmap Pengembangan Energy Storage untuk Smart Grid System. Pusat Teknologi Konversi Energi. Balai Pengakajian dan.Penerapan Teknologi.

[9] Linden, David, and Thomas B. Reddy. 2002. Handbook of Batteries 3 Ed. Amerika Serikat: The McGraw-Hills Companies, Inc.

[10] Kosasih, D. P. 2018. Pengaruh Variasi Larutan Elektrolit pada Accumulator Terhadap Arus dan Tegangan. Dosen Bidang Teknik Material Program Studi Teknik Mesin, Universitas Subang. ISSN: 2355-9241. Hal 33-45.

[11] PT. Century Batteries Indonesia. 2015. Incoe Battery Catalogue. Retrieved July 11, 2020. From: aki.incoe-astra.com.

[12] Iron Edison. 2016. Lithium Batteries for Solar PV. Retrieved July 12, 2020. From: ecorenovator.org.

[13] Afif, M. T., Pratiwi, I. A. P. 2015. Analisis Perbandingan Baterai Lithium ion, Lithium Polymer, Lead Acid, dan Nickel-Metal Hybride Pada Penggunaan Mobil Listrik- Review. Jurnal Rekayasa Mesin. Vol. 6 No. 2. Hal 95-99.

[14] Trojan Battery Company. 2018. Selecting the Proper Lead-Acid Technology Retrieved August 11, 2020. From: www.trojanbattery.com.

[15] Simon Roberts, Solar Electricity: A Practical Guide to Designing and Installing Small Photovoltaic System, Cambridge, UK: Prentice-Hall International Ltd., 1991.

[16] M.R. Patel. Wind and Solar Power System. Washington, DC: CRC Press., 1984.

[17] T. Maskvart dan L. Castaner. Practical Handbook of Photovoltaic. UK: Elsevier Science, Ltd., 2003

[18] Asian Development Bank. 2018. Handbook on Battery Energy Storage System.

[19] D. Rastler, "Electricity Energy Storage Technology Options", Final Report-EPRI, California-USA, December 2010.

[20] Thorbergsson, Egill, Vaciav Knap, Maciej Swierczynski, Daniel Stroe, and Remus Teodorescu. 2013. Primary Frequency Regulation with Li-on Battery Based Energy Storage System. Evaluation and Comparison of Different Control Strategies. Intelec 2013. 35th International Telecommunications Energy Conference. Hamburg, Germany 13-17 October.

[21] Buchman, I. 2001. Batteries in a Portable World : A Handbook on Rechargeable Batteries for Non- Engineers.

[22] Albert, W. Ng., 2018. Solar Energy-Knowledge Base. Net Solar.

[23] Badan Standarisasi Nasional. 2009. Baterai Dikenai SNI Wajib. Retrieved August 29, 2020. From : https://bsn.go.id/main/berita_det/935/Baterai-dikenai-SNI-wajib

[24] Anonim. 2016. Peraturan Menteri Perindustrian Republik Indonesia Nomor 82 Tahun 2016 Tentang Lembaga Penilaian Kesesuaian Dalam Rangka Pemberlakuan dan Pengawasan Standar Nasional Indonesia Baterai Primer Secara Wajib.

[25] International Tin Association, 2017. Lead Acid Batteries Impact on Future tin Use. Technical Report

[26] Astriani, Y., Kurniasari, A., Priandana, E. R., Aryono, N. A. 2018. Penyeimbangan State of Charge Baterai Lead Acid pada Prototipe Battery Management System. Ketenagalistrikan dan Energi Terbarukan, Vol. 17, No. 1 Juni 2018. Hal 43-52.

[27] Victron Energy. Gel and AGM Batteries. Retrieved July 22, 2020. From: www.victronenergy.com

[28] PT. Nippress, Tbk. 2016. NS Accelerate Catalogue. Retrieved August 15, 2020. From: www.nipress.com

[29] Solar Surya Indotama. 2013. Battery Hoppecke-Solar Power. Retrieved August 18, 2020. From : solarsuryaindotama.co.id

[30] Hudaya, Chairul. 2011. Peranan Riset Baterai Sekunder dalam Mendukung Penyediaan Energi Bersih di Indoonesia 2025. Proceeding Olimpiade Karya Tulis Inovatif (OKTI) 2011. Korean Institute of Science and Technology (KIST).

[31] AAF Statistics. 2019. ASEAN Automotive Federation. Retrieved September 5, 2020. From: www.asean-autofed.com 
[32] Nickel Data Sheet-Mineral Commodity Summaries 2020. US Geological Survey. Retrieved September 5, 2020. From: en.wikipedia.org

[33] Ayuningtyas, D. 2019. 4 Pabrik Baterai Mobil Listrik Dibangun, Siapa Untung ?. Retrieved September 4, 2020. From: www.cnbcindonesia.com.

[34] Pinterest. 2018. Peta Indonesia. Retrieved September 4, 2020. From : id.pinterest.com

[35] Anonim, 1999. Peraturan Pemerintah Republik Indonesia No. 18 Tahun 1999 Tentang : Pengelolaan Limbah Bahan Berbahaya dan Beracun.

[36] Salomone, Roberta., Mondello, Fabio., Lanuzza, Francesco., Micali, Giuseppe. 2005. An Ecobalance of a Recycling Plant for Spent LeadAcid Batteries. Environmental Management Vol. 35, No. 2, pp. 206219.

[37] Anonim, 2019. Peraturan Presiden Republik Indonesia Nomor 55 Tahun 2019 Tentang Percepatan Program Kendaraan Bermotor Listrik Berbasis Baterai (Battery Electric Vehicle) untuk Transportasi Jalan.

[38] Anonim, 1995. Keputusan Menteri Negara Lingkungan Hidup. Nomor : KEP-51/MENLH/10/1995. Tentang Baku Mutu Limbah Cair Bagi Kegiatan Industri.

[39] Yen, Ivan Chang., 2002, Basel Caribbean Sub-Regional Centre/Cariri-Uwi Project on Used Lead-Acid Batteries., Final Report, St. Agustine: Ministry of the Environment of Trinidad and Tobago.

[40] Respati, B., Damanhuri, E. 2009. Persebaran Pelaku Daur Ulang Informal Aki Bekas Kendaraan Bermotor di Kota Bandung.

[41] Wilson, David C., Araba, Adebisi O., Chinwah, Kaine, Cheeseman, Christoper R., 2009, Building Recycling Rates Through the Informal Sector., Waste Management Vol. 29, pp. 629-635.

[42] Wilson, David C., Velis, C., Cheeseman, C., 2006. Role of Informal Sector Recycling in Waste Management in Developing Countries. Habitat International 30, 797-808.

[43] Utomo, Y. S. 2013. Uji Performansi Baterai Deep Cycle Sebagai Komponen Sistem PJU LED Tenaga Surya. Conference : Prosiding Seminar Nasional Fisika 2013 Pusat Penelitian Fisika LIPI Serpong. Hal 556-563 ISSN: 2088-4176.

[44] Juharah, W.D. 2013. Analisis Kelistrikan yang Dihasilkan Limbah Buah dan Sayuran Sebagai Energi Alternatif Bio-Baterai. Skripsi. Jurusan Fisika, Universitas Jember.

[45] Yulianti, E., Saputri, R.D., Jodi, H., Salam, R. 2013. Pembuatan Bahan Polimer Elektrolit Padat Berbasis Nanokomposit Kitosin Montmorillonite untuk Aplikasi Baterai. Jurnal Kimia Kemasan, Vol. 35 No. 2. Hal 77-83.

[46] Utomo, Y. S. 2015. Uji Kinerja Baterai Deep Cycle Pada Sistem Pembangkit Listrik Tenaga Surya Photovoltaik. Conference : Prosiding Seminar Nasional Fisika dan Aplikasinya. Program Studi Fisika-FMIPA Universitas Padjajaran Jatinangor. Hal FE8-FE18 ISSN: 2477-0477.

[47] Alfith. 2015. Konfigurasi Baterai Pada Pembangkit Renewable Energy. Jurnal Teknik Elektro ITP Vol. 4 No. 1. Hal 46-50.

[48] Farizy, A. F. 2016. Desain Sistem Monitoring State of Charge Baterai pada Charging Station Mobil Listrik Berbasis Fuzzy Logic dengan Mempertimbangkan Temperatur. Tugas Akhir. Teknik Elektro Institut Teknologi Sepuluh Nopember.

[49] Amri, B. 2016. Photovoltaic Pulse Charge untuk Konfigurasi Penyimpanan Energi Melalui Konsep Charge Management Pada Sistem PV Standalone. Tesis Jurusan Teknik Elektro Institut Sepuluh November.

[50] Pangemanan, G. A. 2017. Kajian Eksperimen Discharge Test pada Baterai $12 \mathrm{~V}$ yang Dihubungkan dengan Motor DC Feedback Tipe No. 63-110 di Laboratorium Listrik dan Otomasi Kapal. Skripsi. Departemen Teknik Sistem Perkapalan Fakultas Teknologi Kelautan, Institut Teknologi Sepuluh Nopember.

[51] Simanjuntak, T. B. O., Mangindaan, G. M. C., Pakiding, M. 2017. Ejournal Teknik Elektro dan Komputer Vol. 6 No. 2. Hal 63-68. ISSN: 2301-8402

[52] Rizkyanto, C. 2018. Analisis Pengaruh Temperatur Terhadap Ketahanan Kontainer Baterai untuk Meningkatkan Service Life pada Free Maintenance Free Battery. Tugas Akhir. Departemen Teknik Mesin, Institut Teknologi Sepuluh Nopember.

[53] Taufik, A., Saputra, R. H., Huda, A.M.M. 2019. Estimasi State of Charge Baterai Regulated Lead Acid Deep-Cycle 12V dengan
Metode Column Counting. Journal of Industrial Engineering and Operation Management. Vol. 2 No. 1. ISSN: 2620-8184.

[54] Zainuri, A., Wibawa, U., Rusli, M., Hasanah, R.N., Harahap, R.A. 2019. VRLA Battery State of Health Estimation Based on Charging Time. TELKOMNIKA, Vol.17, No. 3. Hal 1577-1583. ISSN: 16936930.

[55] Mufidah, I. N., 2019. Estimasi State of Charge pada Baterai VRLA (Valve-Regulated Lead Acid) dengan Metodde Polynomial Regression. Skripsi. Jurusan Teknik Elektro Universitas Jember.

[56] Sugeng, B., Saputra, R. H. 2019. Estimasi State of Charge Menggunakan Simulink pada Baterai Pembangkit Listrik Tenaga Surya. Jurnal Teknik Elektro, Teknologi Informasi dan Komputer, Vol. 3 No. 1. Hal 1-8.

[57] Akhinov, I. A., Handaya, D. 2019. Sistem Kontrol Pengisian Baterai pada Penerangan Jalan Umum Berbasis Solar Cell. Jurnal Teknologi Rekayasa Vol. 4, No. 1. Hal 93-98. p-ISSN: 2548-737X. e-ISSN: 2548-8678.

[58] Rochmawati, I. 2020. Peramalan Kapasitas Baterai Asam Timbal dengan Metode Extreme Learning Machine. Skripsi. Jurusan Teknik Elektro Universitas Jember. 